augural lecture entitled "The Place of Archæology in Indian Studies". The High Commissioner for India, Mr. Krishna Menon, who took the chair, said that the creation of such a chair was very welcome and he hoped that it would lead to exchanges of scholars on both sides. He welcomed the appointment of Prof. Codrington, whose second home was India. In his lecture, Prof. Codrington stressed the educational value of the study of archæology, and the need of close collaboration between all who are interested in the study of India. Outlining the relations of the earliest city culture in India with north and south Persia, he went on to describe the intrusion of the neolithic tanged-adze culture of South-East Asia with reference to the first appearance of the Aryans in India. The chair of Indian archæology in the University of London is held jointly at the Institute of Archæology and the School of Oriental Studies.

\section{Food and Agriculture Organisation}

THE fourth annual conference of the Food and Agriculture Organisation of the United Nations will open in Washington on November 15. The conference will review the world food situation and the technical activities of the Food and Agriculture Organisation. It will also consider major constitutional, administrative and financial issues, particularly the budget for the next financial year. The United Kingdom delegation will be led by Mr. Tom Williams, Minister of Agriculture and Fisheries; the alternate leader is Mr. R. H. Franklin, deputy secretary in the Ministry of Agriculture and Fisheries. Among other members of the delegation will be Sir Ralph Enfield (chief economic adviser) and Mr. A. T. A. Dobson (fisheries adviser), both of the Ministry of Agriculture and Fisheries; Dr. N. C. Wright (chief scientific adviser), of the Ministry of Food; Sir Gerard Clauson, assistant under-secretary of State in the Colonial Office; Mr. P. N. R. Butcher, assistant secretary in the Ministry of Health; Mr. A. N. Duckham, agricultural attaché to the British Embassy; and Mr. G. R. Oake, head of the British Supply Office (Food) in Washington. In addition, Mr. James Turner, president of the National Farmers Union, and Mr. E. G. Gooch, president of the National Union of Agricultural Workers, will serve as advisers to the delegation.

\section{Biological Service in Great Britain}

Mr. Herbert Morrison, Lord President of the Council, announced in the House of Commons on November 1 that Capt. Cyril Diver has been appointed head of the biological service which is to be formed for the conservation of the fauna and flora of Great Britain, including Nature reserves. The London office of the service is at Thorney House, Smith Square, S.W.1.

\section{Society of Chemical Industry: Fine Chemicals Group}

The Fine Chemicals Group of the Society of Chemical Industry has for its objects "The discussion of fine chemicals especially such as are of therapeutic or biological interest". The Group held its inaugural meeting at the Royal Institution on October 5, with Sir Jack Drummond, chairman of the Group, presiding. Prof. J. H. Burn, professor of pharmacology, University of Oxford, delivered the inaugural address and reviewed much of the important work that has been done in the production of fine chemicals for medicinal use. He recalled the lapse of time between the discovery of penicillin in 1929 and its use in 1941, and suggested that, but for the recog. nition of the curative value of sulphonamides, it is possible that the use of penicillin might have been held up indefinitely owing to the false notion that "an antibacterial agent for use in man is an impossibility". Prof. Burn referred particularly to the work in the fields of tuberculosis and cancerous growths, of which the latter is still, in his opinion, the out. standing unsolved problem; it is one thing to deal with bacteria in the blood and extracellular fluid, but quite another thing when the bacterial agents are inside the cell or even in the nucleus. Much knowledge is to be gained from the classical work of Dale and Laidlaw with Carr, Barger and Ewins on adrenaline (and sympathomimetic amines), histamine and acetylcholine. It is increasingly obvious that the effect of chemical substances in the body is to modify or interfere with the action of these three compounds. This matter is of great importance in the study of anæsthetics, and it would be worth while to promote research in this direction. In the general problems of research, Prof. Burn felt that the university worker ought to pass on more of his knowledge to the industrial laboratories, and the industrial men of science must take 'refresher' courses in the academic laboratories to keep abreast of new techniques. The crying need of to-day is not for more fundamental knowledge but more application of the present existing knowledge. In conjunction with this, Prof. Burn expressed the opinion that the value of elaborating quantitative methods for the estimation of biological properties is indisputable. This work has been criticized as not leading to any fundamental discovery; but since 1926 chemical work has been much facilitated by the introduction of biological standards, and the Pharmaceutical Society has made a wise decision in establishing a laboratory for the study of biological standardization.

\section{Cultural Geography of the Tarascan Area, Mexico}

PuB. No. 7 of the Institute of Social Anthropology, Smithsonian Institution, Washington, by Robert C. West, may be specially welcomed because it deals with a population in its environment in western Mexico, and takes note of physical features, climate, agriculture, handierafts, houses and settlements and material culture generally. The geognostic map is an interesting key to the environment and so are the maps, admittedly based on inadequate data none too reliable, of climatic features, especially the frequency of frost on the highlands. Tarascan was an indigenous language of pre-Spanish days; the conquerors misused the natives in mines and elsewhere, missionaries and others 'hispanized' large numbers of the remainder on great estancias (stock-raising farms) and haciendas (crop farms); so the old language lingers only in the poorer areas which Europeans did not wish to occupy. The recession of Tarascan speech is traced in maps for different periods. Wheat and barley were cultivated soon after the Spanish Conquest in order to pay the tribute demanded by the authorities, and Arabic modes of irrigation also came in. Each community had owned surrounding lands in which the chief apportioned the right of user among the villagers. Since the mid-nineteenth century, individual ownership has developed; but vestiges remain, and in some pueblos a head-of-family may have 2-4 hectares allotted sine die provided he does not leave the land untilled for more than two successive years. He may sell his right-of-user, but only to another 